\title{
KODYFIKACJA I POSTĘPOWY ROZWÓJ MIĘDZYNARODOWEGO PRAWA KOSMICZNEGO PRZEZ SOFT LAW
}

\section{WPROWADZENIE - ROZWÓJ MIĘDZYNARODOWEGO PRAWA KOSMICZNEGO A SOFT LAW}

Pojęcia kodyfikacji i postępowego rozwoju prawa międzynarodowego niewątpliwie kojarzą się z funkcjonowaniem Komisji Prawa Międzynarodowego - organu powołanego w 1947 r. przez Zgromadzenie Ogólne Organizacji Narodów Zjednoczonych (ONZ) właśnie w celu realizacji tego procesu ${ }^{1}$. Artykuł 15 Statutu Komisji wyjaśnia, że przez pojęcie „postępowy rozwój prawa międzynarodowego” należy rozumieć „przygotowanie projektów konwencji w przedmiocie, który jeszcze nie był regulowany przez prawo międzynarodowe lub w zakresie którego prawo nie zostało jeszcze w sposób wystarczający rozwinięte przez praktykę państw”. Natomiast „kodyfikacja prawa międzynarodowego" to w świetle tegoż samego artykułu „bardziej precyzyjne formułowanie oraz systematyzacja norm prawa międzynarodowego w obszarach, w których już istnieje obszerna praktyka państw, precedens oraz poglądy doktryny"2.

${ }^{1}$ Komisja była pierwszym stałym organem niezależnych ekspertów w zakresie prawa międzynarodowego; A. Boyle, C. Chinkin, The Making of International Law, Oxford 2007, s. 171; w polskiej literaturze zob. np. K. Wolfke, Rozwój i kodyfikacja prawa międzynarodowego. Wybrane zagadnienia z praktyki ONZ, Wrocław 1972; J. Gilas, Rozwój $i$ kodyfikacja prawa międzynarodowego w praktycznej działalności ONZ: potrzeba artykulacji nowych norm i wzorców zachowań się państw, w: T. Łoś-Nowak (red.), Narody Zjednoczone - między oczekiwaniem a spetnieniem, Wrocław 1995, s. 159-168; M. Szuniewicz, Kodyfikacja a progresywny rozwój prawa międzynarodowego publicznego, „Kwartalnik Prawa Publicznego” 13, 2013, nr 2, s. 27-46.

2 Statut Komisji Prawa Międzynarodowego przyjęty rezolucją Zgromadzenia Ogólnego nr 174 z 21 listopada 1947 r. z późniejszymi zmianami; jak podkreśla się w doktrynie, sformułowana w statucie dychotomia nie była w późniejszym czasie rozwijana teoretycznie przez Komisję z uwagi na trudności w przeprowadzeniu w ramach poszczególnych tematów wyraźnego jednoznacznego podziału na projekty o charakterze wyłącznie kodyfikacyjnym lub opracowania wyłącznie opierające się na postępowym rozwoju prawa, zob. R. Y. Jennings, The progressive development of international law and its codification, „British Yearbook of International Law” 24, 1947, s. 301. W tym kontekście jednak trafnie zauważa Karol Wolfke, że: „Z faktu tego nie wynika, aby można było zrezygnować z rozróżnienia tych zasadniczo odmiennych w swoim założeniu funkcji” (idem, op. cit., s. 18); warto również przypomnieć o funkcjonującym w okresie Ligi Narodów Komitecie 16 prawników powołanych przez Radę Ligii w 1924 r. w celu przedstawienia raportów odnośnie do zagadnień, które są odpowiednie do kodyfikacji. W 1927 r. Komitet przedstawił Radzie 
Komentując ten przepis, Karol Wolfke zauważa, że „w pierwszym przypadku mamy $\mathrm{w}$ każdym razie do czynienia $\mathrm{z}$ tworzeniem nowych norm, tzn. takimi, które przedtem nie istniały, gdyż były w najlepszym razie in statu nascendi w formie rozwijającej się praktyki. W drugim przypadku chodzi już o obowiązujące normy prawa międzynarodowego, które wymagają bądź sformułowania po raz pierwszy na piśmie, bądź przeredagowania i unowocześnienia"3. Komisja Prawa Międzynarodowego nie zajmowała się jednak prawem kosmicznym i pozostawiła pole w tym zakresie powstałemu w 1959 r. Komitetowi ds. Pokojowego Wykorzystania Przestrzeni Kosmicznej ONZ (Committee on the Peaceful Uses of Outer Space - COPUOS) ${ }^{4}$.

Warto przyjrzeć się, jak kodyfikacja i postępowy rozwój międzynarodowego prawa kosmicznego postępowały w ostatnich latach na forum COPUOS, w szczególności w pracach jego podkomitetów - prawnego oraz naukowo-technicznego. Proces ten obejmuje wielu zazębiajacych się tematów, które podejmuja obecnie te dwa organy. Do najistotniejszych można zaliczyć status i zastosowanie pięciu traktatów kosmicznych, zarządzanie ruchem kosmicznym, zastosowanie prawa międzynarodowego do działalności małych satelitów i ograniczanie zanieczyszczania przestrzeni komicznej w Podkomitecie Prawnym oraz wytyczne dotyczace długoterminowego zrównoważonego wykorzystania przestrzeni kosmicznej w Podkomitecie Naukowo-Technicznym. Wybór tylko jednego tematu będącego przedmiotem prac tego ostatniego organu nie powinien tworzyć wrażenia jego mniejszego znaczenia. W rzeczywistości dążenie do wypracowania wytycznych, będące przedmiotem prac grupy roboczej funkcjonujacej w ramach Podkomitetu Naukowo-Technicznego COPUOS od 2010 r., jest obecnie jednym z najbardziej ambitnych przedsięwzięć ONZ dotyczących pokojowego wykorzystania przestrzeni kosmicznej i obejmuje całe spektrum zagadnień politycznych, prawnych, naukowych i technicznych. Dokument, który ma ostatecznie zostać przyjęty w 2018 r., ma opierać się m.in. na istniejaccych traktatach i zasadach ONZ dotyczacych przestrzeni kosmicznej, a także na istniejących praktykach, procedurach, standardach i politykach ${ }^{5}$. Pro-

siedem tematów dotyczących obywatelstwa, morza terytorialnego, odpowiedzialności za szkody wyrządzone cudzoziemcom, immunitetów i przywilejów dyplomatycznych, procedur na konferencjach międzynarodowych, piractwa oraz eksploatacji zasobów morza, zob. szerzej R. Jennings, A. Watts, Oppenheim's International Law, vol. 1: Peace, Oxford 2008, s. 101.

${ }^{3}$ K. Wolfke, op. cit., s. 41; warto jeszcze przytoczyć jeden komentarz tego autora: „Często głoszony pogląd o niemożności oddzielenia rozwoju prawa międzynarodowego od jego kodyfikacji wymaga sprecyzowania. Postępowy rozwój, czyli tworzenie nowych norm, jest możliwe niezależnie od kodyfikacji, choć oczywiście nie powstają one w próżni prawnej i zwykle są poprzedzane przez rozwijającą się praktykę będącą wyrazem potrzeby regulacji prawnej. Możliwa jest też, choć raczej wyjątkowo, kodyfikacja, czyli ściślejsze formułowanie istniejących norm zwyczajowych, które były już przedtem formułowane w partykularnych umowach, w orzecznictwie czy w nauce. Nie można natomiast uznać za kodyfikację [...] przetworzenie normy zwyczajowej w normę traktatowa. Ta czynność [...] to tworzenie nowej normy na podstawie jedynie przybliżonego opisu żywej praktyki uznanej przez państwa za prawo", s. 46-47.

4 COPUOS został ustanowiony rezolucją Zgromadzenia Ogólnego nr 1348 z 13 grudnia 1958 r.

${ }^{5}$ Updated set of draft guidelines for the long-term sustainability of outer space activities, 26.11.2015, A/AC.105/C.1/L.348, pkt 9; Część wytycznych została przyjęta w czerwcu 2016 r. przez COPUOS, zob. Report of the Committee on the Peaceful Uses of Outer Space, Fifty-ninth session (8-17 June 2016), A/71/20 annex. 
jekt wytycznych jest wspierany przez państwa, które posiadaja już rozwiniętą aktywność kosmiczna, ponieważ to szczególnie w ich interesie leży zagwarantowanie możliwości zrównoważonego wykorzystania przestrzeni kosmicznej6.

Warto wyjaśnić, że od wielu lat prace COPUOS nie są ukierunkowane na tworzenie nowych traktatów. Wynika to z faktu, że niektóre państwa nie popieraja tej formy rozwijania współpracy ${ }^{7}$. Dowodem tego zjawiska sa ponadczterdziestoletnie, i nadal trwające, debaty nad definicją oraz delimitacja przestrzeni kosmicznej czy niepowodzenie ambitnego porozumienia regulującego działalność państwa na Księżycu i innych ciałach niebieskich z 5 grudnia 1979 r., które do dzisiaj cieszy się niewielkim poparciem (tylko 17 państw stron) ${ }^{8}$. Zatem mimo dostrzegalnego procesu dynamicznego rozwoju aktywności ludzkości w przestrzeni kosmicznej, z udziałem zarówno państw, organizacji międzynarodowych, jak i podmiotów prywatnych, w ostatnich 40 latach powszechne międzynarodowe prawo kosmiczne ${ }^{9}$ rozwijało się przede wszystkim przez dokumenty o charakterze soft law, które $\mathrm{w}$ istotnym stopniu uzupełniaja traktaty wypracowane na przełomie lat sześćdziesiątych i siedemdziesiątych ${ }^{10}$. W tym zakresie omawiany dział

${ }^{6}$ Report of the Legal Subcommittee on its fifty-fifth session, held in Vienna from 4 to 15 April 2016, 27.04.2016, A/AC.105/1113 [dalej jako: RLS 2016)] pkt 168.

7 Te problemy wiążą się z szerszym zagadnieniem specyfiki i tempa tworzenia prawa międzynarodowego. Według Romana Kwietnia: „Prawo międzynarodowe jawi się jako statyczny i zachowawczy porządek prawny właśnie z uwagi na mozolność procesu tworzenia nowych norm prawnych”, idem, Wartości i prawo a kreatywność porzqdku prawnego, „Forum Prawnicze” 2010, nr 1 , s. 40.

8 Zob. szerzej Ł. Kułaga, Przestrzeń kosmiczna-jako wspólne dziedzictwo ludzkości. Kontrowersje wokót Porozumienia regulujacego działalność państw na Księżycu i innych ciałach niebieskich, w: Z. Galicki, T. Kamiński, K. Myszona-Kostrzewa (red.), Wykorzystanie przestrzeni kosmicznej: Świat, Europa, Polska, Warszawa 2010, s. 25-41.

9 Użycie terminu „powszechne międzynarodowe prawo kosmiczne” ma na celu sprecyzowanie, że punktem odniesienia dla autora są normy o charakterze generalnym i abstrakcyjnym, dostrzega bowiem istnienie praktyki zawierania porozumień dwustronnych czy ograniczonych porozumień wielostronnych dotyczących np. konkretnych projektów, które bez wątpienia również należą do międzynarodowego prawa kosmicznego. Takim przykładem jest Porozumienie międzyrządowe o Międzynarodowej Stacji Kosmicznej z 29 stycznia 1998 r.; zob. szerzej J. Ryzenko, Międzynarodowa Stacja Kosmiczna. Przykład wspótpracy międzynarodowej państw w badaniu i eksperymentalnym wykorzystaniu przestrzeni kosmicznej, w: Z. Galicki, T. Kamiński, K. Myszona-Kostrzewa (red.), op. cit., s. 69-83, oraz Ł. Kułaga, Wspótczesne tendencje regulacyjne $w$ międzynarodowym prawie kosmicznym, „Kwartalnik Prawa Publicznego” 7, 2007, nr 4, s. 57-66.

${ }^{10}$ Do traktatów tych zalicza się: Układ o zasadach działalności państw w zakresie badań i użytkowania przestrzeni kosmicznej, łącznie z Księżycem i innymi ciałami niebieskimi z 27 stycznia 1967 r., Dz. U. 1968, Nr 14, poz. 82, załącznik nr 2; Umowę o ratowaniu kosmonautów, powrocie kosmonautów i zwrocie obiektów wysłanych w przestrzeń kosmiczną z 22 kwietnia 1968 r., Dz. U. 1969, Nr 15, poz. 110; Konwencję o międzynarodowej odpowiedzialności za szkody wyrządzone przez obiekty kosmiczne z 29 marca 1972 r., Dz. U. 1973, Nr 27, poz. 154, załącznik oraz Konwencję w sprawie rejestracji obiektów wysłanych w przestrzeń kosmiczną z 12 listopada 1974 r., Dz. U. 1979, Nr 5, poz. 22, załącznik; zjawisko rozwoju międzynarodowego prawa kosmicznego przez soft law w polskiej doktrynie nie zawsze jest przedmiotem znaczącej uwagi, zob. np. interesujące, aczkolwiek niepodejmujące tego tematu monografie: L. Łukaszuk, Wspótpraca i rywalizacja w przestrzeni kosmicznej, Toruń 2012, czy M. Polkowska, Prawo kosmiczne w nowej erze działalności w kosmosie, Kraków-Warszawa 2015. 
prawa wpisuje się w procesy dotykające również inne dziedziny prawa międzynarodowego ${ }^{11}$. Anna Wyrozumska zauważa, że:

faktem jest, że środki nieformalne są coraz częściej stosowane w stosunkach międzynarodowych, a normy zawarte w aktach, o których mówimy (niewiążące prawnie), zaczynają wywierać znaczacy wpływ na rozwój prawa międzynarodowego ${ }^{12}$.

Wzrost znaczenia dokumentów o charakterze soft law w prawie międzynarodowym wiąże się z upowszechnieniem pojęcia standardów w dyskursie prawnym, które często uznawane są za rozwiązanie wzorcowe o znaczeniu normatywnym, bez względu na to, czy sa one umiejscowione w formalnych źródłach prawa międzynarodowego ${ }^{13}$. Takie podejście umożliwia również znacznie szybsze reagowanie na nowe problemy aniżeli negocjowanie traktatów czy oczekiwanie na wykształcenie się norm zwyczajowych, nawet jeśli uwzględni się potencjalną szybkość rozwinięcia się tych ostatnich w dziedzinie prawa kosmicznego ${ }^{14}$.

W tym kontekście pojęcie kodyfikacji i postępowego rozwoju międzynarodowego prawa kosmicznego będzie stosowane w niniejszym artykule, mając na względzie przedstawiona specyfikę tego działu prawa, tj. rozwój przez przyjmowanie wielostronnych formalnie niewiążących dokumentów zawierających powszechnie akceptowane standardy ${ }^{15}$. Trafnie bowiem wskazuje się, że „aby podjąć współczesne wyzwania w pokojowej eksploracji i wykorzystaniu

${ }^{11}$ R. Bierzanek, „Miękkie” prawo międzynarodowe, „Sprawy Międzynarodowe” 1987, nr 1, s. 91-106; R. Bierzanek, Some remarks on „soft” international law, „Polish Yearbook of International Law” 17, 1988, s. 21-41; P. Szwedo, O pojęciu globalnego prawa administracyjnego, „Forum Prawnicze" 2011, nr 8, s. 60-77; M. Menkes, Governance gospodarczy - studium prawnomiędzynarodowe, Warszawa 2016, s. 57-76; M. Kenig-Witkowska, Soft law w międzynarodowym prawie środowiska. Uwagi na marginesie katalogu źródet prawa, w: T. Giaro (red.), Źródta prawa - Teoria i praktyka, Warszawa 2016, s. 359-375.

${ }_{12}$ A. Wyrozumska, Instrumenty międzynarodowe niewiażace prawnie (soft law lub flexible law), w: A Łazowski, R. Ostrihanski (red.), Wspótczesne wyzwania europejskiej przestrzeni prawnej. Ksiega pamiatkowa dla uczczenia 70. urodzin Profesora Eugeniusza Piontka, Kraków 2005, s. 617; zob. również K. Skubiszewski, Rola niewiażacych uchwat normatywnych $w$ prawotwórstwie międzynarodowym, „Państwo i Prawo” 41, 1986, z. 1, s. 34-45.

${ }^{13}$ Zob. szerzej Ł. Kułaga, Traktowanie sprawiedliwe $i$ stuszne $w$ międzynarodowym prawie inwestycyjnym, Warszawa 2016, s. 25-40.

${ }_{14}$ Według Sergia Marchisio: „w ostatnich latach państwa we wzrastającym stopniu polegały na niewiążących porozumieniach w celu zarządzania aktywnościa w przestrzeni kosmicznej i praktyka ta ulega konsolidacji [...]. Mimo że niewiążące - one [niewiążące ramy - przyp. Ł.K.] pokazuja stanowcze oczekiwanie odpowiedzialnego zachowania od uczestniczacych państw, odzwierciedlając wartości i aspiracje grupy, która je akceptuje", idem, Space Law and Governance, http://www.unoosa.org/pdf/SLW2016/Opening/2._Marchisio_MARCHISIO_10th_United_Nations_Workshop_on_Space_Law.pdf, s. 10-11 (tłum. Ł.K.) [dostęp: 12.12.2017].

${ }^{15}$ Warto przy tym odnotować, że również Komisja Prawa Międzynarodowego uznaje dokumenty prawnie niewiążące za niekiedy wartościowy rezultat swoich prac $\mathrm{w}$ zakresie kodyfikacji i postępowego rozwoju prawa międzynarodowego, przyjmując dokumenty w postaci: przewodników dla praktyków (zastrzeżenia do traktatów 2011 r.), raportów (zobowiązanie do osądzania lub wydania 2014 r., klauzula najwyższego uprzywilejowania 2015 r.), wytycznych przewodnich (akty jednostronne państw 2006 r.), czy zasad (alokacja strat w przypadku transgranicznej szkody wynikającej z niebezpiecznej działalności 2006 r.). 
przestrzeni kosmicznej, konieczne jest uzyskanie lepszego rozumienia niewiążących prawnie instrumentów oraz praktyk ich dotyczących"16.

Zasadność przyjęcia takiej perspektywy do analizy rozwoju międzynarodowego prawa kosmicznego potwierdza również przedostatnia część artykułu prezentująca zjawisko wprowadzania przez państwa do porządków krajowych standardów wypracowanych/wyznaczonych na forum COPUOS i przyjętych przez Zgromadzenie Ogólne (ZO) w formie rezolucji.

Ostatnia część artykułu przedstawia zakończoną niepowodzeniem próbę konsolidacji współczesnego międzynarodowego prawa kosmicznego podjęta przez Unię Europejska (UE) w formie projektu Międzynarodowego kodeksu postępowania dotyczącego działań w przestrzeni kosmicznej (dalej również jako: Kodeks). Klęska tego przedsięwzięcia pokazuje równocześnie, że nie należy idealizować możliwości rozwoju prawa kosmicznego przez soft law. Uznanie, że celem procesu międzynarodowego jest jedynie stworzenie dokumentu niewiążącego w żadnym stopniu, nie daje gwarancji jego przyjęcia. W tym kontekście zatem doświadczenie prac nad Kodeksem stanowi przestroge przed idealizowaniem przewagi dokumentów soft law nad traktatami.

\section{KODYFIKACJA MIĘDZYNARODOWEGO PRAWA KOSMICZNEGO}

Proces kodyfikacji w międzynarodowym prawie kosmicznym może być postrzegany również przez wzrost znaczenia normatywnego standardów funkcjonujących przede wszystkim na podstawie rezolucji Zgromadzenia Ogólnego NZ lub innych niewiążących uzgodnień o charakterze międzynarodowym. W tej perspektywie kodyfikacja stanowi swoista systematyzację wytycznych, niebędących przedmiotem zasadniczych kontrowersji, w obszarach, w których istnieje już gruntowna praktyka państw.

Tendencja dostrzegalna w pracach COPUOS to wzmacnianie znaczenia standardów wypracowanych wcześniej przez ten organ, które nie są przedmiotem regulacji traktatowej. Taka praktyka pozwala równocześnie na uniknięcie dyskusji nt. wykształcenia się analogicznych norm prawa zwyczajowego, co niezwykle często pozostaje przedmiotem kontrowersji, mimo że-jak wskazuje Komisja Prawa Międzynarodowego - prawo kosmiczne to specyficzny dział, w którym prawo zwyczajowe powstaje niekiedy niezwykle szybko ${ }^{17}$. Nie rozstrzygajac kwestii, w jakiej mierze standardy wypracowane przez COPUOS moga być uznane za normy prawa zwyczajowego, gdyż pozostaje ona poza zakresem niniejszego artykułu, stwierdzić należy, że bez wątpienią zwiększa się znaczenie normatywne szeregu rozwiązań prawnych w tym zakresie.

\footnotetext{
${ }^{16}$ New agenda item on general exchange of information on non-legally binding United Nations instruments on outer space, Working paper submitted by Japan, and co-sponsored by Austria, Canada, France, Nigeria and the United States of America, 10.06.2013, A/AC.105/2013/ CRP.6.

17 International Law Commission Report 2016, A/71/10, s. 96.
} 
Projekt wytycznych dotyczących długoterminowego zrównoważonego wykorzystania przestrzeni kosmicznej, mający w dużym stopniu charakter kodyfikacyjny, uwypukla znaczenie normatywne następujących standardów:

1) zasady dotyczące wykorzystania źródeł energii atomowej w przestrzeni kosmicznej zawarte w rezolucji ZO nr 47/68 z 14 grudnia 1992 r. (wytyczna $2.2 \mathrm{e})$

2) rekomendacje w sprawie ustawodawstwa krajowego dotyczacego pokojowego wykorzystania przestrzeni kosmicznej zawarte w rezolucji ZO nr 68/74 z 16 grudnia 2013 r. (wytyczna 1.3);

3) wytyczne dotyczace ograniczenia zanieczyszczenia przestrzeni kosmicznej zawarte w rezolucji ZO nr 62/217 z 22 grudnia 2007 r. (wytyczna 2.2b);

4) rekomendacje w zakresie wzmocnienia praktyki państw i organizacji międzyrządowych w odniesieniu do rejestracji obiektów kosmicznych zawarte w rezolucji ZO nr 62/101 z 10 stycznia 2008 r. (wytyczna 6.1);

5) ramy bezpieczeństwa (ang. safety framework) zastosowania źródeł energii atomowej $\mathrm{w}$ przestrzeni kosmicznej przygotowane przez Podkomitet Naukowo-Techniczny COPUOS we współpracy z Międzynarodową Agencja Energii Atomowej w 2009 r. (wytyczna 2.2e) ${ }^{18}$.

Projekt wytycznych dotyczących zrównoważonego wykorzystania przestrzeni kosmicznej, z założenia dokument należący do kategorii soft law, odwołuje się zatem do konieczności czy też zasadności przestrzegania innych instrumentów niewiążących dotyczących istotnych zagadnień z zakresu wykorzystania przestrzeni kosmicznej - nieregulowanych zasadniczo przez podstawowe traktaty kosmiczne. Znaczenie tego procesu można ocenić, mając również na uwadze fakt, że szereg - wydawałoby się istotnych - standardów dotyczących przestrzeni kosmicznej nie zostało uwzględnionych w projekcie wytycznych ${ }^{19}$. Tym samym omawiany dokument dokonuje swoistej kodyfikacji oraz systematyzacji, tj. podnosi wagę pewnych regulacji prawnych zawartych $\mathrm{w}$ aktach charakterze soft law, a marginalizuje inne.

\section{POSTĘPOWY ROZWÓJ MIĘDZYNARODOWEGO PRAWA KOSMICZNEGO}

Postępowy rozwój międzynarodowego prawa kosmicznego, w świetle uwarunkowań przedstawionych we wprowadzeniu, jest rozumiany w niniejszym artykule jako przygotowanie projektów standardów w przedmiocie, który jeszcze nie był regulowany przez dokumenty soft law dotyczące tego działu prawa.

\footnotetext{
${ }^{18}$ Guidelines for the long-term sustainability of outer space activities - Working paper by the Chair of the Working Group on the Long-term Sustainability of Outer Space Activities, 7.02.2017, A/AC.105/C.1/2017/CRP.29.

${ }_{19}$ Do „wielkich nieobecnych” można zaliczyć: Zasady rządzące wykorzystaniem przez państwa sztucznych satelitów Ziemi dla międzynarodowej bezpośredniej transmisji telewizyjnej rezolucja ZO nr 37/92 z 10 grudnia 1982r.; Zasady dotyczące obserwacji satelitarnej Ziemi z kosmosu - rezolucja ZO nr 41/65 z 3 grudnia 1986 r., oraz Zastosowanie reguł odnoszących się do „państwa wysyłającego” - rezolucja ZO 59/115 z 10 grudnia 2004 r.
} 
Do tego rodzaju zagadnień można zaliczyć zarządzanie ruchem kosmicznym czy znaczenie wzrostu działalności małych satelitów. Te dwa tematy dotyczą zasadniczo podobnych problemów. Znaczenie kwestii zarządzania ruchem kosmicznym (ang. space traffic management) zwiększa się z uwagi na fakt, że środowisko kosmiczne staje się coraz bardziej zagęszczone. Wynika to z rosnącej liczby obiektów kosmicznych, wzrostu aktywności kosmicznej poszczególnych obiektów oraz liczby podmiotów zaangażowanych w ten proces ${ }^{20}$. Nie ma powszechnie akceptowanej definicji zarządzania ruchem kosmicznym, niemniej warto odnotować propozycję z raportu podkomitetu prawnego COPUOS z 2016 r., gdzie wskazuje się, że może ono być rozumiane jako

zestaw technicznych i regulacyjnych postanowień promujących bezpieczeństwo dostępu do przestrzeni kosmicznej, operacje w prowadzone w tej przestrzeni oraz powrót na ziemię wolny od ingerencji fizycznej lub w odniesieniu do wykorzystywanych częstotliwości radiowych ${ }^{21}$.

Problematyka ta powinna również uwzględniać nowe aspekty wykorzystywania przestrzeni kosmicznej, w szczególności wzrost liczby małych satelitów oraz nanosatelitów. To ostatnie zjawisko może bowiem istotnie wpływać m.in. na możliwości manewrowania obiektami kosmicznymi, zakłócania ich działalności i możliwości kolizji oraz procedury kończenia operacji w przestrzeni kosmicznej22.

Projekt wytycznych dotyczących długoterminowego zrównoważonego wykorzystania przestrzeni kosmicznej pośrednio odnosi do zarządzania ruchem kosmicznym w dziale dotyczącym bezpieczeństwa operacji kosmicznych (część B). Podkreśla się w nim konieczność stworzenia mechanizmów, czy procedur, które ograniczyłyby prawdopodobieństwo kolizji obiektów kosmicznych, obejmujących m.in.:

- wielopoziomową wymianę informacji w zakresie obiektów kosmicznych oraz zdarzeń orbitalnych (wytyczna 11.1-5 oraz wytyczna 31);

- opracowanie jednolitych standardów w zakresie ustalania danych orbitalnych obiektów kosmicznych (wytyczna 12);

- przeprowadzanie zbiorczej oceny podczas wszystkich orbitalnych etapów lotu obiektu kosmicznego w odniesieniu do trajektorii lotu innych obiektów kosmicznych (wytyczna 14);

- przeprowadzanie oceny przed wypuszczeniem obiektu kosmicznego w przestrzeń kosmiczną w zakresie możliwych zderzeń takiego obiektu z innymi obiektami znajdującymi w obszarze przestrzeni kosmicznej bliskiej Ziemi (wytyczna 15);

- wymianę informacji nt. pogody kosmicznej (pkt 16);

- uwzględnienie w procesie podejmowania decyzji dotyczącej usunięcia obiektu kosmicznego wymogów bezpieczeństwa, w tym przyjęcie środków oraz przeprowadzenie oceny zmierzajacych do zapobieżenia zagrożeniom wynikającym z takiej operacji, w szczególności w odniesieniu do innych obiektów kosmicznych (wytyczna 20);

\footnotetext{
20 RLS 2016, pkt 205.

${ }^{21}$ Ibidem, pkt 207-208.

22 Ibidem, pkt 213 oraz załącznik nr 1 pkt 10 .
} 
- ustanowienie niezbędnych procedur dla bezpiecznego przeprowadzenia operacji zniszczenia obiektu kosmicznego na orbicie, tak aby unikać zanieczyszczenia przestrzeni kosmicznej oraz zagrożenia dla życia i mienia zarówno w przestrzeni kosmicznej, jak i na Ziemi (wytyczne 21-22) oraz

- przestrzeganie środków ostrożnościowych w przypadku używania przez podmioty znajdujące się w jurysdykcji lub pod kontrolą państwa laserów, które generuja wiązi przechodzace przez obszar przestrzeni kosmicznej bliskiej Ziemi (wytyczna 32$)^{23}$.

\section{KODYFIKACJA I POSTĘPOWY ROZWÓJ PRAWA KOSMICZNEGO A PRAWO KRAJOWE}

Istotne znaczenie standardów w międzynarodowym prawie kosmicznym dobrze odzwierciedla wstęp do pierwszego projektu wytycznych dotyczących długoterminowego zrównoważonego wykorzystania przestrzeni kosmicznej z 2015 r. ${ }^{24}$ Wskazywano w nim, że stanowią one

międzynarodowy konsensus w zakresie środków potrzebnych do wzmocnienia długoterminowego zrównoważonego wykorzystania przestrzeni kosmicznej (pkt 10) [oraz że] państwa, międzypaństwowe organizacje międzynarodowe oraz krajowe i międzynarodowe podmioty niepaństwowe powinny dobrowolnie podjąc środki [...] w celu zapewnienia, że wytyczne zostaną implementowane w największym możliwie i praktycznie stopniu (pkt 17).

Wytyczne miały być wdrażane w dobrej wierze (pkt 19), a w odniesieniu do odpowiedzialności państw za działania w przestrzeni kosmicznej określono, że państwa nie powinny powoływać swojego interesu narodowego ani krajowej polityki lub legislacji dla przeprowadzania operacji sprzecznych z wytycznymi $(\text { pkt } 3.2)^{25}$.

W odniesieniu do szczegółowych postanowień aktualny projekt określa, że państwa powinny implementować wytyczne dotyczące ograniczenia zanieczyszczenia przestrzeni kosmicznej oraz zasady dotyczące wykorzystania źródeł energii atomowej w przestrzeni kosmicznej. Te ostatnie w opinii autorów projektu wytycznych mają szczególne znaczenie, ponieważ zmniejszają ryzyko zagrożenia zdrowia publicznego i bezpieczeństwa w działalności w przestrzeni kosmicznej. Podobnie w pkt 28.2 projektu określa się, że należy „zwiększyć przestrzeganie" wytycznych dotyczących ograniczenia zanieczyszczenia przestrzeni kosmicznej, a w pkt 6.6 wskazuje, że państwa i organizacje międzynarodowe powinny postępować zgodnie z odpowiednimi postanowieniami rezolucji ZO nr 62/101 dotyczącej rejestracji obiektów kosmicznych.

${ }^{23}$ Guidelines for the long-term sustainability of outer space activities - Working paper by the Chair of the Working Group on the Long-term Sustainability of Outer Space Activities, 7.02.2017, A/AC.105/C.1/2017/CRP.29.

${ }^{24}$ Updated set of draft guidelines for the long-term sustainability of outer space activities, 26.11.2015, A/AC.105/C.1/L.348.

${ }_{25}$ Guidelines for the long-term sustainability of outer space activities - Working paper by the Chair of the Working Group on the Long-term Sustainability of Outer Space Activities, 7.02.2017, A/AC.105/C.1/2017/CRP.29. 
Potwierdzeniem znaczenia tych rozwiązań jest fakt, że zgodnie z przygotowanym przez polskie Ministerstwo Rozwoju projektem założeń do projektu ustawy o Krajowym Rejestrze Obiektów Kosmicznych z 3 lutego 2016 r. od polskiego podmiotu wnioskującego o wpis do krajowego rejestru obiektów kosmicznych wymaga się m.in. „przedstawienia informacji nt. zastosowanych technik ograniczających zanieczyszczanie przestrzeni kosmicznej i deorbitacji obiektu po zakończonej misji”"26. Takie rozwiązanie legislacyjne funkcjonuje już w ustawodawstwie wielu państw (m.in. Stanów Zjednoczonych, Austrii, Kanady i Francji) ${ }^{27}$. Co znaczace, problematyka zapobiegania zanieczyszczania przestrzeni kosmicznej nie jest przedmiotem regulacji żadnego z czterech podstawowych traktatów kosmicznych.

Przejawem tego zjawiska jest również fakt, że Wielka Brytania i Francja przedstawiły już informacje, jak w swoim prawie i praktyce krajowej wprowadzają niektóre wytyczne dotyczące długoterminowego zrównoważonego wykorzystania przestrzeni kosmicznej ${ }^{28}$. Swoiste wdrażanie wytycznych do porządku krajowego potwierdza pogląd A. Wyrozumskiej, zakładający, że:

akty niewiążące prawnie [...] tworzą ekspektatywę, że zachowanie państw [...] będzie zgodne z niewiążącymi zasadami postępowania [...] ich skutek wynika z zasady dobrej wiary ${ }^{29}$.

\section{MIĘDZYNARODOWY KODEKS POSTĘPOWANIA DOTYCZĄCY DZIAŁAŃ W PRZESTRZENI KOSMICZNEJ}

Międzynarodowy kodeks postępowania dotyczący działań w przestrzeni kosmicznej to unijna inicjatywa stanowiąca odpowiedź na rezolucję Zgromadzenia Ogólnego nr 61/75 z 6 grudnia 2006 r. Zgodnie z pkt 1 rezolucji ZO

zaprosiło wszystkie państwa do przedstawienia Sekretarzowi Generalnemu [...] konkretnych propozycji w zakresie przejrzystości oraz środków budowy zaufania w interesie międzynarodowego pokoju i bezpieczeństwa oraz promowania międzynarodowej współpracy i zapobiegania wyścigowi zbrojeń w przestrzeni kosmiczneje ${ }^{30}$.

${ }^{26}$ Zob. https://legislacja.rcl.gov.pl/docs//1/242743/242774/242775/dokument207085.pdf, s. 16 [dostęp: 12.12.2017].

${ }^{27}$ Zob. np. Art 5 Loi no 2008-518 du 3 juin 2008 relative aux opérations spatiales, http:// download.esa.int/docs/ECSL/France.pdf, § 4 austriackiej Bundesgesetz über die Genehmigung von Weltraumaktivitäten und die Einrichtung eines Weltraumregisters, http://www.unoosa. org/oosa/en/ourwork/spacelaw/nationalspacelaw/index.html; czy § 31501 amerykańskiej ustawy National and Commercial Space Programs, http://uscode.house.gov/download/annualhistoricalarchives/pdf/2010/2010usc51.pdf; pkt 12 zał. 1 do kanadyjskich Remote Sensing Space Systems Regulations, http://laws-lois.justice.gc.ca/eng/regulations/SOR-2007-66/FullText.html [dostęp: 12.12.2017].

${ }^{28}$ „The United Kingdom's implementation of the first set of guidelines for the long-term sustainability of outer space activities", 27.01.2017 r., A/AC.105/C.1/2017/CRP.21.; General presentation of French activities and views for the long-term sustainability of outer space activities, in relation with the implementation of the first set of guidelines (A/71/20, annex), 3.02.2017, A/AC.105/C.1/2017/CRP.26.

${ }^{29}$ A. Wyrozumska, op. cit., s. 632.

${ }^{30} 61 / 75$. Transparency and confidence-building measures in outer space activities, $\mathrm{A} / \mathrm{RES} / 61 / 75,18.12 .2006$. 
Ponadto określając uwarunkowania, które wymagają przyjęcia Kodeksu, znaczną uwagę zwrócono na problemy zanieczyszczenia oraz zarządzania ruchem w przestrzeni kosmicznej:

Zasoby kosmiczne eksploatowane przez coraz większą liczbę podmiotów rządowych i pozarządowych oferuja światu ogromne korzyści, [...] tym korzyściom towarzyszą ważne wyzwania wynikające z niebezpiecznych śmieci kosmicznych, które moga powodować destrukcyjne kolizje, ze stłoczenia satelitów na orbicie geostacjonarnej, rosnącego nasycenia widma częstotliwości radiowych oraz groźby celowych zakłóceń. Te wyzwania wymagaja poważnego zaangażowania wszystkich państw, tak aby zapewnić większe bezpieczeństwo i ochronę przestrzeni kosmicznej ${ }^{31}$.

Unijna propozycja projektu Kodeksu została przedstawiona w czerwcu 2012 r. i do lipca 2015 r. odbyły się 4 rundy konsultacji, z czego w trzech pierwszych spotkaniach uczestniczyli przedstawiciele ponad 60 państw, a w ostatnim ponad $100^{32}$.

Zgodnie z pkt 1.1 projektu Kodeksu jego celem ,jest zwiększenie poziomu bezpieczeństwa, ochrony i zrównoważonego charakteru wszystkich działań dotyczących obiektów kosmicznych oraz środowiska kosmicznego" ${ }^{33}$. W pkt 2 Kodeks określa zasady ogólne, które stanowią rozwinięcie zasad wynikających z podstawowych traktatów dotyczących przestrzeni kosmicznej. W szczególności poza uznaniem „swobod[y] wszystkich państw w zakresie dostępu, badania i użytkowania przestrzeni kosmicznej”, podkreśla się również wymóg „pełnego poszanowania bezpieczeństwa, ochrony i integralności obiektów kosmicznych oraz zgodności z uznanymi międzynarodowymi praktykami, operacyjnymi procedurami, standardami technicznymi oraz politykami powiąanymi ze zrównoważonym wykorzystaniem przestrzeni kosmicznej”. Podkreślono również

${ }^{31}$ Decyzja Rady (WPZiB) 2015/203 z 9 lutego 2015 r. wspierająca propozycję Unii odnosząca się do międzynarodowego kodeksu postępowania dotyczącego działań w przestrzeni kosmicznej jako wkładu w środki na rzecz przejrzystości i budowy zaufania w zakresie działań w przestrzeni kosmicznej, Dz. Urz. UE z 10 lutego 2015 L 33/38, załącznik pkt 1; teza ta znajduje potwierdzenie w faktach, np. „11 lutego 2009 roku korporacja Iridium Satellite LLC potwierdziła kolizję swojego satelity telekomunikacyjnego (o masie $560 \mathrm{~kg}$ ) z niesprawnym rosyjskim satelita (o masie $900 \mathrm{~kg}$ ), w wyniku której możliwe były zakłócenia w zabezpieczeniu przez firmę łączności satelitarnej. Do zderzenia doszło na wysokości ok. $790 \mathrm{~km}$, w następstwie czego powstała znacznych rozmiarów chmura śmieci kosmicznych. W opinii NASA przypadek ten jest drugim w kolejności tak znaczącym incydentem, w wyniku którego ilość powstałych śmieci kosmicznych stwarza znaczące zagrożenie dla urządzeń poruszających się na niskiej orbicie okołoziemskiej”, R. Borek, Powstawanie i rozprzestrzenianie śmieci kosmicznych w świetle przepisów Unii Europejskiej, „Obronność - Zeszyty Naukowe Wydziału Zarządzania i Dowodzenia Akademii Obrony Narodowej” 2016, nr 1(17), s. 19-29.

${ }^{32}$ Rundy konsultacji odbyły się: 16-17 maja 2013 r. w Kijowie, 20-22 listopada 2013 r. w Bangkoku, 27-28 maja 2014 r. w Luksemburgu oraz 29 czerwca-2 lipca 2015 r. w Nowym Jorku; zob. decyzja Rady (WPZiB) 2015/203 z 9 lutego 2015 r. wspierająca propozycję Unii odnoszącą się do międzynarodowego kodeksu postępowania dotyczącego działań w przestrzeni kosmicznej jako wkładu w środki na rzecz przejrzystości i budowy zaufania w zakresie działań w przestrzeni kosmicznej, preambuła pkt 8.

33 Draft International Code of Conduct for Outer Space Activities, version 31 March 2014, https://eeas.europa.eu/sites/eeas/files/space_code_conduct_draft_vers_31-march-2014_en.pdf [dostęp: 12.12.2017]. 
„odpowiedzialność państw do podjęcia wszelkich odpowiednich środków oraz współpracy w dobrej wierze w celu uniknięcia szkodliwej ingerencji w działalność w przestrzeni kosmicznej”. W pkt 3 projektu Kodeksu państwa potwierdzają swoje zobowiązania wynikające nie tylko z traktatów, ale również zasad i wytycznych obejmujących szereg rezolucji $\mathrm{ZO}^{34}$. Kodeks przewiduje wymóg przyjęcia środków w zakresie ograniczenia zanieczyszczeń przestrzeni kosmicznej, mechanizm notyfikacji o działaniach w przestrzeni kosmicznej oraz konsultacji (pkt 4-8).

Szczególnie istotne dla losów Kodeksu okazało się zakończone fiaskiem ostatnie spotkanie w 2015 r. Nowym Jorku. Przyczyn tego stanu rzeczy upatruje się $\mathrm{w}$ podniesionych przez przeciwników inicjatywy wadach proceduralnych spotkania, polegajacych na braku mandatu UE ze strony ONZ dla rzeczywistych negocjacji Kodeksu oraz prawa każdego państwa do przedstawienia alternatywnego tekstu dokumentu. Podkreśla się przy tym, że brak poparcia Federacji Rosyjskiej oraz Chińskiej Republiki Ludowej był jedna z kluczowych przyczyn odrzucenia projektu. Państwa te kontynuują promowanie na forum Konferencji rozbrojeniowej alternatywnej inicjatywy, tj. projektu Traktatu o zapobieganiu umieszczania broni w przestrzeni kosmicznej, groźbie oraz użyciu siły przeciwko obiektom kosmicznym ${ }^{35}$. Znaczące przy tym jest, że sprzeciw Chin i Rosji wobec projektu jest łączony z faktem niewiążącego charakteru Kodeksu, podczas gdy konieczne jest uregulowanie problemu rozbrojenia w przestrzeni kosmicznej na gruncie traktatowym ${ }^{36}$. Niemniej uzasadnienie to wydaje się pozorne, biorąc pod uwagę, że projekt Kodeksu poza krótki akapitem preambularnym (,Noting the importance of preventing an arms race in outer space”) w ogóle nie odnosił się do kwestii rozbrojenia.

\section{ZAKOŃCZENIE}

Specyfika rozwoju międzynarodowego prawa kosmicznego powoduje konieczność podjęcia rozważań nad redefinicją klasycznych pojęć prawa międzynarodowego dotyczących jego kodyfikacji i postępowego rozwoju. Dobrze oddaje ten kierunek definiowanie przez COPUOS niedawno stworzonej koncepcji zarządzania ruchem kosmicznym, jako obejmującej regulacje wynikajace zarówno z podstawowych traktatów kosmicznych, jak i z dokumentów soft law, z których te ostatnie zdają się odgrywać coraz większą rolę. Zgodzić się bowiem należy z poglądem, że „zarządzenie ruchem w przestrzeni kosmicznej nie jest konceptualnie uregulowane $\mathrm{w}$ traktatach i w rezultacie mają one ogra-

341721 z 1961 r., 1962 z 1963 r., 47/68 z 1992 r., 51/122 z 1996 r., 59/91 z 2002 r., 62/101 z 2007 r. oraz 62/217 z 2007 r.

${ }^{35}$ M. J. Listner, The International Code of Conduct: comments on changes in the latest draft and post-mortem thoughts, „The Space Review” 26.10.2015.

${ }^{36}$ J. Bryła, Bezpieczeństwo państwa w świetle teorii dóbr publicznych, „Przegląd Strategiczny” 2013, nr 1, s. 134; M. Zenko, A Code of Conduct for Outer Space, Policy innovation memorandum, no. 10, 30.11.2011, https://www.cfr.org/sites/default/files/pdf/2011/11/Policy_Innovation_ Memo10_Zenko.pdf [dostęp: 12.12.2017]. 
niczone znaczenie"37. Podobnego rodzaju fenomenem jest projekt wytycznych dotyczaccych zrównoważonego rozwoju przestrzeni kosmicznej oraz standardy w zakresie zapobiegania zanieczyszczeniom tego obszaru.

Zaprezentowane w artykule podejście ukierunkowane na analize rozwoju standardów formalnie niewiążących prawnie jest uzasadnione, gdyż pozwala lepiej zrozumieć dynamikę zmian w międzynarodowym prawie kosmicznym. Wyłącznie klasyczne podejście oparte na źródłach prawa międzynarodowego, za których katalog powszechnie uznaje się art. 38 Statutu Międzynarodowego Trybunału Sprawiedliwości, nie pozwoliłoby dostrzec niebagatelnego procesu rozwoju międzynarodowego prawa kosmicznego, który następuje mimo braku nowych globalnych regulacji traktatowych po $1979 \mathrm{r}$.

Równocześnie przykład niepowodzenia inicjatywy międzynarodowego kodeksu postępowania dotyczącego działań w przestrzeni kosmicznej pokazuje, że metoda regulacji w drodze rozwijania soft law nie stanowi uniwersalnego panaceum na trudności normotwórcze społeczności międzynarodowej. Podobnie jak w przypadku negocjacji traktatów, państwa przykładaja do kształtowania tego rodzaju dokumentów duże znaczenie. W rezultacie wypracowanie kompromisowego tekstu - nawet formalnie niewiążących dokumentów - okazuje się niełatwe, szczególnie gdy państwa uznają daną kwestię za istotną dla swoich interesów. Mimo że proces negocjacji kluczowych dokumentów o charakterze soft law w porównaniu z procesem zawierania umów międzynarodowych zdaje się czasochłonny, nadal istotną korzyścia tych pierwszych jest brak konieczności przeprowadzania żmudnych procedur ratyfikacyjnych. Wbrew pozorom ta szybkość często nie jest powiąana z kosztem braku skuteczności w prawie krajowym, ponieważ państwa sa gotowe dobrowolnie wprowadzać normy soft law ze względu na doniosłość regulowanej przez nie problematyki.

dr Łukasz Kułaga

Uniwersytet Kardynała Stefana Wyszyńskiego w Warszawie

l.kulaga@uksw.edu.pl

\author{
CODIFICATION AND PROGRESSIVE DEVELOPMENT \\ OF INTERNATIONAL SPACE LAW THROUGH SOFT LAW
}

Summary

The article suggests the reinterpretation of classical international law terms: the codification and progressive development, in order to carry out an in-depth analysis of the development processes in international space law. Since no new global treaties in this regard have been made since 1979, an instrument which seems to allow for substantial changes in international space law is soft law norms. In this context, codification in international space law can also be understood as enhancement of the normative importance of standards that are mainly con-

${ }^{37}$ A. Soucek, Perspectives on future space traffic management, http://www.unoosa.org/pdf/ SLW2016/Panel1/3._Soucek_Future_perspectives_of_space_traffic_management_Soucek_final. pdf, s. 6 [dostęp: 12.12.2017]. 
tained in the resolutions adopted by the General Assembly. Consequently, codification may be considered as a systematisation of guidelines which create no controversies in fields where there has already been extensive State practice in place. Similarly, progressive development of international space law can be understood as a preparation of drafts of standards on subjects not yet regulated by soft law documents. At the same time, the failure of the initiative of the International Code of Conduct for Outer Space Activities shows that the soft law method of regulation cannot be considered as a universal remedy to address the difficulties of international communities in the process of norm creation. 
